\title{
REPRESENTATIONAL PRACTICES AT THE INTERNATIONAL CRIMINAL COURT: THE GAP BETWEEN JURIDIFIED AND ABSTRACT VICTIMHOOD
}

\author{
SARA KENDALL* \\ SARAH NOUWEN $* *$ \\ They cannot represent themselves; they must be represented. ${ }^{1}$
}

Karl Marx

I

\section{REPRESENTATIONAL PRACTICES AT THE INTERNATIONAL CRIMINAL COURT}

Representation is one of the most ingrained practices at the International Criminal Court (ICC). ${ }^{2}$ ICC defense counsel engage in probably the best known practice of representation by directly representing the interests of the accused. But the prosecutor and the chambers also represent: The prosecutor prosecutes and the chambers adjudicate on behalf of-at minimum-all the states that have ratified the Rome Statute of the International Criminal Court (Rome Statute). ${ }^{3}$ If the court has jurisdiction over a situation pursuant to a UN Security Council referral, the prosecutor and chambers also act on behalf of all member

Copyright (C) 2014 by Sara Kendall \& Sarah Nouwen.

This article is also available at http://lcp.law.duke.edu/.

* Researcher, Grotius Centre for International Legal Studies, Leiden University. E-mail: s.kendall@cdh.leidenuniv.nl.

** Lecturer in Law and Fellow of the Lauterpacht Centre for International Law, Fellow of Pembroke College, University of Cambridge. E-mail: smhn3@cam.ac.uk. The authors are grateful for the constructive feedback on this paper, including from participants in a session of the International Studies Association, taking place in San Francisco in March 2013, where an earlier version of this paper was presented. (Sarah Nouwen's participation was made possible by a generous conference grant from European Cooperation in Science and Technology (COST).)

1. KARL MARX, THE EIghtEenTH BRUMAIRE OF LOUIS BonAPARTE 124 (Foreign Languages Publishing House 1960) (1852). The Marx citation also appears as an epigraph to EDWARD W. SAID, ORIENTALISM (1979).

2. In line with the approach of Jens Meierhenrich in this issue, see Jens Meierhenrich, The Practice of International Law: A Theoretical Analysis, 76 LAW \& CONTEMP. PROBS., nos. 3-4, 2013 at 1, 10-27, the term "practice" is used as Emanuel Adler and Vincent Pouliot used it in International Practices, 3 INT'LTHEORY 1, 4 (2011): “[P]ractices are socially meaningful patterns of action, which, in being performed more or less competently, simultaneously embody, act out, and possibly reify background knowledge and discourse in and on the material world."

3. Rome Statute of the Int'l Criminal Court, July 17, 1998, 2187 U.N.T.S. 90 (entered into force July 1, 2002) [hereinafter Rome Statute]. 
states of the United Nations. This article focuses on a more novel practice of representation in international criminal law: the practice of speaking, directly or indirectly, for victims of international crimes.

Like other practices, the practice of representation produces effects. ${ }^{4}$ Political and social theorists have studied the effects of the practice of political representation. As this article will show, some of their insights illustrate the effects of legal representation as well, despite formal differences in representational practice. One such insight is that, as Hanna Pitkin explains, representation is "re-presentation, a making present again" that is not merely a "literal bringing into presence" but a "making present in some sense of something which is nevertheless not present literally or in fact." For Pitkin, representational practice is characterized by the absence of the object of representation: Some other entity carries out this act of "making present," introducing a rhetorical space where claims are made on behalf of absent constituents. ${ }^{6}$ In the field of law, practices of representation also allow various actors to stand in for others and to make claims on their behalf. Unlike the defendant, a disembodied concept such as "the state" or "the international community" is not physically present in the courtroom.

When constituents are absent, representation produces what Pierre Bourdieu refers to as an "oracle effect": A "spokesperson gives voice to the group in whose name he speaks, thereby speaking with all the authority of that elusive, absent phenomenon." In politics, Bourdieu writes, a "whole series of symbolic effects ... rest on this sort of usurpatory ventriloquism, which consists in giving voice to those in whose name one is authorized to speak." ${ }^{8}$ The oracle effect that is produced through representational practices of speaking on behalf of others thus entails an appropriation or "usurpation" of the voices (and indeed authority) of the represented. This oracle effect is evident at the ICC as well. When the prosecutor prosecutes or the judges adjudicate international crimes-whether they do so on behalf of states that have ratified the Rome Statute, or on behalf of member states of the United Nations, or even on behalf of "the victims" of international crimes-these actors simultaneously "give voice to" and appropriate the voices and authority of those they claim to represent.

But the relationship between the representative and the represented is more dynamic than one in which the representative merely usurps authority from the represented: The relationship is mutually constitutive. As Bourdieu argues, the representative is both constituted by and constitutes the represented group: "It is because the representative exists, because he represents (symbolic action), that the group that is represented and symbolized exists and that in return it

4. See Meierhenrich, supra note 2, at 20-27.

5. HANNA F. PitKin, THE CONCEPT OF REPRESENTATION 8-9 (1967) (emphases omitted).

6. Id.

7. Pierre Bourdieu, LANGUAGE AND Symbolic Power 211 (1991).

8. Id. 
gives existence to its representative as the representative of the group." This circular relationship between representative and represented exists in law as well. While the representative relies upon the represented entity to confer the representative's authority, the represented entity-whether a defendant, a victim, the crown, or the "international community"-relies upon the representative to make it present.

As a practice, representation is thus built upon a series of presumptions about transferring authority from one individual (or collective) to another, about the ability to speak on behalf of others, and about the resilience of individual (and plural) interests when they are channelled through a singular representative.

Against this theoretical background we review the representation of the interests of a new category of actors in international criminal law: "victims.", 10 According to the ICC website, the rights granted to victims under the Rome Statute and the ICC's Rules of Procedure and Evidence (RPE) are "[o]ne of the [ICC's] great innovations." 11 Apart from the right to reparations (which is beyond the focus of this article), the website mentions the right to participate in proceedings: "For the first time in the history of international criminal justice, victims have the possibility ... to present their views and observations before the Court.... The victim-based provisions within the [Rome] Statute provide victims with the opportunity to have their voices heard." 12 Similarly, a guidebook for victim participants in ICC proceedings explains:

In order to ensure that the voices of victims are heard and their interests taken into account during proceedings, victims at the ICC enjoy rights that have never before been incorporated in the mandate of an international criminal court.

9. Id. at 204 .

10. The term "victims" is controversial, since it is associated with the image of a "powerless, helpless innocent" who suffers from catastrophic events but lacks agency him or herself. See MAKAU Mutua, Human Rights: A POLITICAL AND Cultural CRITIQUE 11 (2002). In the specific context of the ICC, Adam Branch notes that the ICC's model of "international human rights advocacy tries to reduce the survivor of violence to a victim." See ADAM BRANCH, DISPLACING HUMAN RIGHTS: WAR AND INTERVENTION IN NORTHERN UGANDA 195 (2011). "Survivor" may indeed be a more appropriate term. For the purposes of this article the term "victims" is used nonetheless, since this is the term used in the Rome Statute and in the discourse of international criminal justice more broadly. One of the reasons for this usage may be that not all "victims" have in fact "survived" international crimes. Rule 85(a) of the ICC's Rules of Procedure and Evidence defines victims as "natural persons who have suffered harm as a result of the commission of any crime within the jurisdiction of the Court." Int'l Criminal Court, Assembly of States Parties, 1st Sess., Sept. 3-10, 2002, Official Records, pt. II.A., ICC Doc. ICC-ASP/1/3 and Corr.1 (Sept. 9, 2002) [hereinafter Int'l Criminal Court, RPE], available at http://www.icc-cpi.int/en_menus/icc/legal\%20texts\%20and\%20tools/official\%20journal/Documents/ RulesProcedureEvidenceEng.pdf (setting forth the ICC's Rules of Procedure and Evidence). Rule 85(b) also provides for recognition of organizations or institutions as victims. Id.

11. Victims and Witnesses, INT'L CRIM. CT., http://www.icc-cpi.int/en_menus/icc/0structure\% 20of\%20the\%20court/victims/Pages/victims\%20and\%20witnesses.aspx (last visited Jan. 20, 2014).

12. Id.

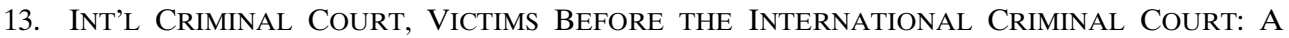
Guide FOR THE PARTICIPATION OF VICTIMS IN THE PROCEEDINGS OF THE COURT 12, available at http://www.icc-cpi.int/NR/rdonlyres/8FF91A2C-5274-4DCB-9CCE-37273C5E9AB4/282477/160910 
Legal scholars and nongovernmental organizations (NGOs) alike have welcomed the fact that the ICC statute allows for direct participation in the proceedings as a progressive step in international criminal law. ${ }^{14}$ The practices of the ad hoc tribunals for the former Yugoslavia (ICTY) and Rwanda (ICTR) were criticized for largely neglecting the interests of conflict-affected individuals. ${ }^{15}$ In ICTY and ICTR proceedings, as in common-law systems, victims had a role only as witnesses. Victims were thus juridically relevant only to the extent that they provided legally relevant information; they did not have a participatory role in their own right. By contrast, the ICC's constituting document, the Rome Statute, was drafted to include a role in the proceedings for victims as victims. Recognized as "actors" in international criminal proceedings, ${ }^{16}$ victims became participants with interests to be represented. In

VPRSBookletEnglish.pdf.

14. See, e.g., Antonio Cassese, The Statute of the International Criminal Court: Some Preliminary Reflections, 10 EUR. J. INT'L L. 144, 167-68 (1999) (claiming that victims of crimes under the Rome Statute are "central to the notion of international criminal justice" and that the relevant statutory article conferring their participatory rights "marks a great advance in international criminal procedure"); Emily Haslam, Victim Participation at the International Criminal Court: A Triumph of Hope Over Experience?, in THE PERMANENT InTERNATIONAL CRIMINAL COURT: LEgAL AND POLICY Issues 315 (Dominic McGoldrick, Peter Rowe \& Eric Donnelly eds., 2004) (noting a "widespread assumption that victims either do or can benefit from participating in international criminal proceedings."). For more critical readings, see Christine H. Chung, Victims' Participation at the International Criminal Court: Are Concessions of the Court Clouding the Promise?, 6 Nw. U. J. INT'L. HuM. RTS. 459 (2008), Håkan Friman, The International Criminal Court and Participation of Victims: A Third Party to the Proceedings?, 22 LEIDEN J. INT'L. L. 485 (2009), and Christine Van den Wyngaert, Victims before International Criminal Courts: Some Views and Concerns of an ICC Trial Judge, 44 CASE W. RES. J. INT'L L. 475 (2011). Christine Van den Wyngaert was an ICC judge when she wrote the article, id., and still serves as one, see Judge Christine Baroness Van den Wyngaert (Belgium), INT'L CRIM. CT., http://www.icc-cpi.int/en_menus/icc/structure \%20of\%20the \%20court/chambers/the $\% 20$ judges/Pages/judge \%20christine\%20van\%20den\%20wyngaert\%20_belgium_.aspx (last visited Jan. 20, 2014). For an example of NGO support for the inclusion of victim participants, see the International Criminal Court (ICC) page on the website of the Fédération international des ligues des droits de l'Homme, http://www.fidh.org/en/international-justice/international-criminal-court-icc/ (last visited Jan. 20, 2014) ("The adoption of the Statute setting up the International Criminal Court (ICC), on 17 July 1998, has been a historical step in the fight against impunity for the most serious crimes. For the first time, victims have the right to participate directly in international criminal proceedings.").

15. See, e.g., Theo van Boven, Victims' Rights and Interests in the International Criminal Court, in The Legal Regime of the InTERnational CRiminal Court: EsSAys in Honour OF PROFESSOR IGOR BLISHCHENKO 898, 898 (Jose Doria, Hans-Peter Gasser \& M. Cherif Bassiouni eds., 2009) (observing that "the ICTY Statute and Rules place victims largely in an accessory role. As witnesses they serve the interests of criminal justice. Nevertheless the Rules related to restitution and compensation open up, albeit in a limited and embryonic fashion, a possibility for the Tribunal to assist the victims in obtaining reparation and justice for themselves. But it appears that these provisions were included in the Rules as a symbolic afterthought rather than that they were expected to produce concrete results"). Claude Jorda and Jerôme de Hemptinne note that the Rome Statute "appears to mark a new step forward.... [V]ictims are accorded the double status denied to them by the provisions setting up the ad hoc tribunals." The Status and Role of the Victim, in THE ROME STATUTE OF THE INTERNATIONAL CRIMINAL COURT: A COMMENTARY 1387, 1387-88 (Antonio Cassese, Paola Gaeta, \& John R. W. D. Jones eds., 2002).

16. Luis Moreno-Ocampo, Prosecutor, Int'l Criminal Court, Statement at the Review Conference - General Debate 2 (May 31, 2010), available at http://www.icc-cpi.int/iccdocs/asp_docs/RC2010/ Statements/ICC-RC-statements-LuisMorenoOcampo-ENG.pdf ("The Rome Statute established 
theory, the counsel representing victims are granted a direct mandate from the victims to represent their interests at trial. ${ }^{17}$

But the role of victims in the ICC's representational practices goes beyond being represented in court proceedings. More indirectly and abstractly, actors both within and outside the ICC have invoked victims' interests as a telos of the work of the ICC-sometimes together with other ends such as "the rule of law" or "ending impunity." From within the ICC, the court's first prosecutor once contended, "My mandate is justice; justice for the victims." 18 And at a press conference in Côte d'Ivoire, his successor claimed that she had opened an investigation in that country "for the victims - to give them a voice." She added, "The sole raison d'être of the ICC's activities in Côte d'Ivoire is the victims and the justice they deserve." 19 The court's president has also suggested that victims are dependent on the court for redress, claiming that "[w]e must not let down the countless victims around the world that place their hope in this institution." ${ }^{20}$ Furthermore, judges have invoked the interests of victims as a basis for their decisions. For instance, the appeals chamber rejected a defendant's admissibility challenge, stating,

This object and purpose of the Statute would come to naught were the said interpretation of article 17(1) of the Statute as proposed by the Appellant to prevail .... Impunity would persist unchecked and thousands of victims would be denied justice.

From outside the ICC, international civil servants supporting the court's creation have claimed that victims' interests are fundamental to the court's work. UN Secretary-General Kofi Annan stated at the beginning of the

victims as actors of international justice.").

17. For an account of the system of victim representation at the ICC, see BRIANNE MCGONIGLE LEYH, PROCEDURAL JUSTICE? VICTIM PARTICIPATION IN INTERNATIONAL CRIMINAL PROCEEDINGS (2011).

18. Press Release, Office of the Prosecutor, ICC Prosecutor Visits Egypt and Saudi Arabia, ICC Press Release ICC-CPI-20080509-MA13 (May 2008), available at http://www.icc-cpi.int/en_menus/ icc/press $\% 20$ and $\% 20$ media/press $\% 20$ releases/press $\% 20$ releases $\% 20(2008) /$ Pages/press $\% 20$ release $\% 2$ 0media\%20advisory_\%20icc\%20prosecutor\%20visits\%20egypt\%20and\%20saudi\%20arabia.aspx [hereinafter Press Release, Office of the Prosecutor, ICC Prosecutor Visits Egypt and Saudi Arabia].

19. Press Release, Office of the Prosecutor, Statement to the Press by the Prosecutor of the International Criminal Court (Abidjan, Côte d'Ivoire, 20 July 2013), ICC Press Release (July 20, 2013), available at http://www.icc-cpi.int/en_menus/icc/press\%20and\%20media/press\%20releases/Pages/ statement-otp-20-07-2013.aspx [hereinafter Press Release, Office of the Prosecutor, Prosecutor's Statement to the Press from Abidjan].

20. Press Release, Office of the Prosecutor, ICC Launches Commemorations for 17 July International Criminal Justice Day, ICC Press Release ICC-CPI-20120706-Pr822 (July 6, 2012), available at http://www.icc-cpi.int/en_menus/icc/press \%20and\%20media/press\%20releases/news \% 20and\%20highlights/Pages/pr822.aspx [hereinafter Press Release, Office of the Prosecutor, ICC Launches Commemorations for International Criminal Justice Day].

21. Prosecutor v. Katanga, Case No. ICC-01/04-01/07, Judgment on the Appeal of Mr. Germain Katanga against the Oral Decision of Trial Chamber II of 12 June 2009 on the Admissibility of the Case, Appeals Chamber Doc. No. 1497, If 79 (Sept. 25, 2009), http://www.icc-cpi.int/iccdocs/ doc/doc746819.pdf. By the authors' request, the journal has agreed to deviate from conventional citation practice by including the names of issuing authorities and specific document numbers in citations to ICC cases. 
negotiations on the Statute in Rome: "The overriding interest must be that of the victims, and of the international community as a whole." ${ }^{22}$ International NGOs have also attempted to orient the project of the ICC around the interests of victims. As one international NGO stated at the occasion of the first conference for the review of the Rome Statute,

One thing is very clear: victims want justice.... More than an abstract ideal, it is a very tangible means by which victims, communities and countries can regain confidence in their ability to live, and to live in peace. Their aspirations must be reflected in your discussions here .... We ask only that over the next couple of weeks you keep one picture at the forefront of your minds: the thousands of children, women and men who are victims of crimes within the Court's jurisdiction, who have been disenfranchised and deprived of the right to live their lives in peace.

Addressing themselves to legal representatives of states, civil-society organizations such as this NGO argue that victims' aspirations "must be reflected in your discussions here." This imperative to represent or stand in for the figure of the absent victim permeates the discourse of those who "practice" international criminal law-whether as lawyers, diplomats or activists-both within and outside the court.

Academic commentary on the ICC has reinforced this imperative, with international legal scholars arguing that victims are the proper beneficiaries of the ICC's work. For example, an established international criminal law scholar noted,

The Conference Chair and leadership of the Assembly of States Parties have a daunting task before them to... emerge from Kampala with a Court that is strengthened rather than weakened by the difficult conversations that will need to take place on the shores of Lake Victoria. Let us hope, for the sake of the victims, that they are able to do so.

Much academic commentary on the court presumes that the court is-or ought to be-animated by and attentive to the interests of victims, in whose name the court is often said to act or speak.

All of these actors within and outside the ICC claim that victims are represented through its work. Depending on the position of the speaking subject-whether the prosecutor, the judges, civil-society organizations, or academic commentators-the court's representative relationship to victims is taken to be either a descriptive fact or a normative assertion. Victims are

22. Press Release, Secretary-General, UN Secretary-General Declares Overriding Interest of International Criminal Court Conference Must Be That of Victims and World Community as a Whole, U.N. Press Release SG/SM/6597 L/2871 (June 15, 1998) [hereinafter Press Release, Secretary-General, UN Secretary-General Declares Overriding Interest of International Criminal Court Conference Must Be That of Victims and World Community as a Whole].

23. Niccolò Figà-Talamanca, Secretary General, No Peace Without Justice, Statement of No Peace Without Justice: Review Conference of the Rome Statute for the International Criminal Court (May 31, 2010) (transcript available at http://www.npwj.org/sites/default/files/documents/ NFT_Statement_ICCReviewConference_01JUN10.pdf).

24. Leila N. Sadat, On the Shores of Lake Victoria: Africa and the Review Conference for the International Criminal Court 16-17 (Washington Univ. in St. Louis, Legal Studies Research Paper No. 10-06-04, 2010), available at $\mathrm{http}: / /$ papers.ssrn.com/sol3/papers.cfm?abstract_id=1626323. 
represented directly, as particular individuals with a name (or, as is usually the case in ICC proceedings, a pseudonym) and indirectly, rhetorically, as the raison d'être of the International Criminal Court.

This article focuses on these two practices of victim representation: the representation of victims as participants in ICC trials, and the discursive invocation of victims as the telos of the court's work. These two practices lead in different directions. The former leads to the "juridification" of victimhood: the legal categorization of victims. The application of legal rules to all actual victims results in a narrowing, like a pyramid, of the victims that are considered "legally relevant." The latter, namely that of abstract representation, draws out victimhood from all victims - dead or alive, past, present, or future-and consolidates this as one. The result of the abstract representation is the creation of a deity-like and seemingly sovereign entity, "The Victim," which transcends all actual victims and corresponds to no individual victims in their particularity. This figure of "The Victim" is deployed as a kind of new sovereign of international criminal law, yet its looming presence in the discourse surrounding the work of the ICC overstates the role of actual victims within the legal proceedings.

II

\section{"JURIDIFIED VICTIMHOOD"-NARROWING THE PYRAMID}

Thinking outside the frame of international criminal law, millions if not billions of people have reason to consider themselves victims, individually or as part of a group. They are victimized by poverty, family abuse, hunger, floods, diseases, human-rights violations, financial crises, armed conflict, and inequality. If victimhood is conceptualized as a pyramid, this broad category of individuals who have suffered would form its base.

However, victimhood as a legal category-juridified victimhood-is much narrower than that massive base. The legal process narrows the category of legally "recognized" victims. Legal parameters give the pyramid of juridified victimhood its shape. The first substantial narrowing occurs because not all causes of victimhood are recognized as international crimes, let alone crimes within the jurisdiction of the ICC. Financial crises, malaria, and poverty, for instance, transform billions of individuals into some form of victim. For a number of reasons, including complex chains of causation, these events hardly ever lead to individual criminal responsibility or to a role for these victims in international criminal proceedings. Indeed, even clear human-rights violations, such as abhorrent living conditions in camps for internally displaced people, are not categorized as international crimes, and these victims thus remain unrecognized within the frame of international criminal law. Even in cases of armed conflict, only very few victims of that conflict will be recognized as victims in international criminal law: Victims of physical violence, and in some cases their relatives, could be recognized; victims of the situation of war "alone"-who live in camps for displaced persons, experiencing a lack of food 
and opportunities—do not qualify, because their predicament is not recognized as an "international crime."

Recognition by law determines which voices are heard in the courtroom and which are not. For instance, in the first situation referred to the ICC, that of northern Uganda, the court recognized some victims of physical violence ${ }^{25}$ but did not recognize individuals who had "only" suffered from the conditions produced by more than two decades of conflict. As it happens, many of the unrecognized victims were initially opposed to the ICC's intervention because of the negative consequences they thought it would have for any future peace process. ${ }^{26}$ In the courtroom, however, only the opinions of those victims who had registered for participation in the ICC proceedings, and were therefore (tacitly) in favor of ICC proceedings, received recognition. ${ }^{27}$ Consequently, only the voices of individuals who support the ICC process and who have sometimes quite literally been "bought into" it, with intermediaries presenting the prospect of reparations, are heard as emanating from legally recognized victims. ${ }^{28}$ Victims of crimes outside the vocabulary of international criminal law are excluded from participation, as are those who oppose the ICC process as a means of redressing their suffering. The selection reflects what Balakrishnan Rajagopal

25. Prosecutor v. Kony, Otti, Odhiambo \& Ongwen, Case No. ICC-02/04-01/05, Decision on Victims' Applications for Participation a/0010/06, a/0064/06 to a/0070/06, a/0081/06 to a/0104/06 and a/0111/06 to a/0127/06, Pre-Trial Chamber II Doc. No. 252 (Aug. 10, 2007), http://www.icc-cpi.int/ iccdocs/doc/doc311910.pdf.

26. See, e.g., Lucy Hovil \& Zachary Lomo, Whose Justice? Perceptions of Uganda's Amnesty Act 2000: The Potential for Conflict Resolution and Long-Term Reconciliation 20 (Refugee Law Project, Working Paper No. 15, 2005), available at http://www.refugeelawproject.org/files/working_papers/ RLP.WP15.pdf.

27. See, e.g., Kony, Otti, Odhiambo \& Ongwen, Case No. ICC-02/04-01/05, Observations on Behalf of Victims Pursuant to Article 19(1) of the Rome Statute with 55 Public Annexes and 45 Redacted Annexes, Pre-Trial Chamber II Doc. No. 349 (Nov. 18, 2008), http://www.icc-cpi.int/iccdocs/ doc/doc589023.pdf.

28. In the ICC's Darfur situation, Sudanese citizens who disagreed with the ICC's proceedings hired lawyers to represent them as amicus curiae, who sometimes were allowed to make submissions, see, e.g., Situation in Darfur, Sudan, Case No. ICC-02/05, Decision on Application Under Rule 103, Pre-Trial Chamber I Doc. No. 185 (Feb. 4, 2009), http://www.icc-cpi.int/iccdocs/doc/doc627395.pdf, and sometimes not, see, e.g., Situation in Darfur, Sudan, Case No. ICC-02/05, Decision on the Filing of Annex 4 to the Application Under Rule 103, Pre-Trial Chamber I Doc. No. 224 (May 18, 2009), http://www.icc-cpi.int/iccdocs/doc/doc689806.pdf. In the northern Uganda situation, a delegation of critical Ugandans visited the court and was received by the Registry and Office of the Prosecutor, but they did not have legal standing. Their views were also largely ignored: Although the Acholi leaders asked the Office of the Prosecutor to be mindful of the peace process and dialogue, the Office of the Prosecutor issued arrest warrants three months later. See Press Release, Registrar, Delegation from Uganda Holds Talks with the Registrar of the ICC, ICC Press Release ICC-CPI-20050318-94 (Mar. 16, 2005), available at http://www.icc-cpi.int/en_menus/icc/situations $\% 20$ and $\% 20$ cases/situations/ situation $\% 20 \mathrm{icc} \% 200204 /$ press $\% 20$ releases/Pages/delegation $\% 20$ from $\% 20$ uganda $\% 20$ holds $\% 20$ talks $\% 20$ with\%20the \%20registrar\%20of\%20the\%20icc.aspx; see also Press Release, Office of the Prosecutor, Statements by ICC Chief Prosecutor and the Visiting Delegation of Acholi Leaders from Northern Uganda, ICC Press Release ICC-OTP-20050318-95 (Mar. 18, 2005), available at http://www.icc-cpi.int/en_menus/icc/situations \%20and\%20cases/situations/situation \%20icc\%200204/ press $\% 20$ releases/Pages/statements $\% 20$ by $\% 20$ icc $\% 20$ chief $\% 20$ prosecutor $\% 20$ and $\% 20$ the $\% 20$ visiting $\% 20$ delegation $\% 20$ of $\% 20$ acholi $\% 20$ leaders.aspx. 
might describe as the "somewhat tragic reality that resistance must work, to some extent, within the parameters established by that which is being resisted." 29

Further narrowing of the pyramid of legally "relevant" victims occurs as a result of the Office of the Prosecutor's selection of situations in which it opens investigations. $^{30}$ This selection is partially dependent on whether the UN Security Council uses its power to refer situations concerning states that are not parties to the statute. But with respect to the 122 States Parties to the statute, the Office of the Prosecutor (OTP) can use its own initiative to open an investigation provided that the pre-trial chamber approves. ${ }^{31}$ As a result of the OTP's selection thus far, some victims in the Democratic Republic of the Congo and Kenya, among others, have been able to obtain legal recognition; victims in Gaza, Afghanistan, Iraq, and Colombia have not.

Once a situation has been selected, the temporal, geographical, and personal parameters of the situation further narrow the pyramid of recognized victims. Thus, as a result of the court's temporal jurisdiction, victims of crimes committed before 2002-when the statute entered into force-will generally not be recognized as victims. ${ }^{32}$ The temporal jurisdiction can be even more limited in a given situation. ${ }^{33}$ For instance, a report from the ICC's Victims Participation

29. BALAKRISHNAN RAJAGOPAL, INTERNATIONAL LAW FROM BELOW: DEVELOPMENT, SOCIAL MOVEMENTS, AND THIRD WORLD RESISTANCE 10 (2003).

30. In the situation of the Democratic Republic of the Congo, Pre-Trial Chamber I made the following distinction between situations and cases:

Situations, which are generally defined in terms of temporal, territorial, and in some cases personal parameters, such as the situation in the territory of the Democratic Republic of the Congo since 1 July 2002, entail the proceedings envisaged in the Statute to determine whether a particular situation should give rise to a criminal investigation as well as the investigation as such. Cases, which comprise specific incidents during which one or more crimes within the jurisdiction of the Court seem to have been committed by one or more identified suspects, entail proceedings that take place after the issuance of a warrant of arrest or a summons to appear.

Situation in the Democratic Republic of the Congo, Case No. ICC-01/04, Decision on the Applications for Participation in the Proceedings of VPRS 1, VPRS 2, VPRS 3, VPRS 4, VPRS 5 and VPRS 6, PreTrial Chamber I Doc. No. 101-tEN-Corr, II 65 (Jan. 17, 2006), http://www.icc-cpi.int/iccdocs/doc/ doc183441.pdf (citations omitted). A victim can be recognized as a victim in a situation or as a victim in a case or both. Only case victims can participate in proceedings during the trial phase.

31. See Rome Statute, supra note 3, at art. 15.

32. Victims of continuing crimes are a possible exception. Discrimination between victims on the ground of the ICC's temporal jurisdiction occurs not only in legal proceedings, but also in academic work. One edited volume on the ICC's complementarity principle, for instance, states in its opening pages, "[t]his book is dedicated to all those victims who suffered harm from mass atrocities since the entry into force of the Statute of the International Criminal Court." Dedication, in THE InTERNATIONAL CRIMINAL COURT AND COMPLEMENTARITY: FrOM THEORY TO PRACTICE (Carsten Stahn \& Mohamed El Zeidy eds., 2011).

33. The temporal jurisdiction has implications for victims beyond participation. For instance, the Trust Fund for Victims, created pursuant to article 79 of the Rome Statute, supra note 3, provides assistance only to victims of crimes committed within the temporal jurisdiction of the court. In northern Uganda this has meant that victims of mutilations allegedly committed by the Lord's Resistance Army after July 2002 qualified for surgical assistance and victims of such mutilations prior to that date did not. Interview by Sarah Nouwen with field program officer, Trust Fund for Victims, Int'l Criminal 
and Reparations Section (VPRS) concerning the Kenyan situation notes that a "range of self-characterized 'victim' or 'survivor' populations exist, including many who suffered harm as a result of periods of violence which fall outside the jurisdiction of the Court." ${ }^{34}$ The VPRS nonetheless focuses its attention "on those victim populations who appear to have suffered harm due to [the] political violence of $2007-2008,{ }^{, 35}$ a period that falls within the jurisdiction of the court. ${ }^{36}$

Geographically the prosecutor's selection of situations has an impact on who can be recognized as a victim. In the Democratic Republic of the Congo, for instance, the OTP has opened investigations in only a few regions. Victims in other areas of the country cannot be legally recognized as victims in ICC proceedings unless another investigation is opened or the scope of an existing investigation is expanded. Common references to "Congolese victims" as a general category conceal the court's narrow geographical gaze.

Whether victims can be legally recognized as such also depends on which group or groups the OTP investigates. In northern Uganda, for instance, some victims of crimes allegedly committed by the Lord's Resistance Army can be legally recognized. Victims of crimes allegedly committed by the Ugandan armed forces cannot, however, because the OTP has not opened an investigation into the forces' actions during the conflict. ${ }^{37}$

The pyramid narrows further when the OTP decides to bring a case: Only victims of the prosecutor's specific charges (a specific act at a specific time at a specific location) can be recognized as participants in the proceedings. Thus, victims of the charged crimes-for example, children recruited as child soldiers or peacekeepers in a camp under attack-can be recognized, but victims of crimes not charged-such as victims of crimes committed by child soldiers or villagers outside the camp—cannot. ${ }^{38}$ The charges limit not merely the acts-for instance, killing, rape, or the recruitment of child soldiers-of which people can be recognized as victims, but also the events (acts at a particular time in a

Court, in Gulu, Uganda (Sept. 2008).

34. Situation in the Republic of Kenya, Case No. ICC-01/09, Public Redacted Version of Report Concerning Victims' Representations (ICC-01/09-6-Conf-Exp) and annexes 2 to 10, Pre-Trial Chamber II Doc. No. 6-Red, II 21 (May 29, 2010), http://www.icc-cpi.int/iccdocs/doc/doc853213.pdf.

35. Id.

36. See Situation in the Republic of Kenya, Case No. ICC-01/09, Decision Pursuant to Article 15 of the Rome Statute on the Authorization of an Investigation into the Situation in the Republic of Kenya, Pre-Trial Chamber II Doc. No. 19 (Mar. 31, 2010), http://www.icc-cpi.int/iccdocs/doc/ doc854562.pdf (authorizing an investigation in relation to crimes against humanity within the jurisdiction of the court committed between June 1, 2005 and November 26, 2009).

37. For an account of the political dimensions of these decisions, see BRANCH, supra note 10, at 179-215.

38. See Prosecutor v. Lubanga, Case No. ICC-01/04-01/06, Judgment on the Appeals of the Prosecutor and the Defence against Trial Chamber I's Decision on Victims' Participation of 18 January 2008, Appeals Chamber Doc. No. 1432, II II 40-66 (July 11, 2008), http://www.icc-cpi.int/iccdocs/doc/ doc529076.pdf; see also Prosecutor v. Abu Garda, Case No. ICC-02/05-02/09, Public Redacted Version of "Decision on the 52 Applications the Pre-Trial Stage of the Case," Pre-Trial Chamber I Doc. No. 147-Red, IIII 130-41 (Oct. 9, 2009), http://www.icc-cpi.int/ iccdocs/doc/doc758050.pdf. 
particular place). Speaking on behalf of former child soldiers that he was appointed to represent, a lawyer in Prosecutor $v$. Katanga observed that victims "still do not understand why only one event has led to charges. I have met with dozens of victims, and many wonder why other events were deemed to be not within the jurisdiction of the Court." ${ }^{39}$

As with the prosecutor, the judges can also narrow the pyramid. One instance in which they do so is when they decide, in accordance with the evidentiary standard, that the prosecutor has not provided sufficient evidence to confirm the charges. In the Kenyan situation, for example, the judges' refusal to confirm charges against the sole person accused of the particular crimes of police violence-the former commissioner of police-meant that victims of police violence lost their juridical status as victims in the case..$^{40}$ (They could remain victims in the situation. $)^{41}$

Not only substantive criteria but also procedural requirements narrow the pyramid. Victims who meet all of the material conditions may still not be legally recognized as victims because they are unaware of their eligibility to apply for victim participation or do not manage to meet the procedural conditions. ${ }^{42}$ For instance, the application forms-available for download on the court's website in English and French, the court's two working languages-are seven pages long and considerably complex. ${ }^{43}$ They are not easily accessible to people without internet access or reading skills, and they require supplemental identifying documents that can be difficult and costly to obtain. At a seemingly most practical, but in fact most existential level, applying for participation

39. Prosecutor v. Katanga, Case No. ICC-01/04-01/07, Transcript of Trial Hearing, Doc. No. T-80ENG, 42:23-25 (Nov. 24, 2009), http://www.icc-cpi.int/iccdocs/doc/doc785434.pdf (statement of JeanLuis Gilissen, legal representative of child soldier victims, in translation from French).

40. Prosecutor v. Kenyatta (Kenya II), Case No. ICC-01/09-02/11, Decision on the Confirmation of Charges Pursuant to Article 61(7)(a) and (b) of the Rome Statute, Pre-Trial Chamber II Doc. No. 382-Red (Jan. 23, 2012), http://www.icc-cpi.int/iccdocs/doc/doc1314543.pdf (refusing to confirm charges against former Commissioner Mohammed Hussein Ali). Victims lost their status in the case because there were no other individuals accused of the same crimes against whom the charges were confirmed. Id. By contrast, in the Darfur situation the court refused to confirm the charges against Bahar Idriss Abu Garda, Prosecutor v. Abu Garda, Case No. ICC-02/05-02/09, Decision on the Confirmation of Charges, Pre-Trial Chamber I Doc. No. 243-Red (Feb. 8, 2010), http:/www.icc-cpi.int/iccdocs/doc/ doc819602.pdf, but did confirm the same charges against Abdallah Banda Abakaer Nourain and Saleh Mohammed Jerbo Jamus, Prosecutor v. Banda, Case No. ICC-02/05-03/09, Corrigendum of the "Decision on the Confirmation of Charges," Pre-Trial Chamber I Doc. No. 121-Corr-Red (Mar. 7, 2011), http://www.icc-cpi.int/iccdocs/doc/doc1036947.pdf.

41. For the difference between a "situation" and a "case," see supra note 30.

42. For example, the head of the VPRS has noted the "many practical and logistical considerations" that affect victim participation, including the challenge of "how to inform victims about the ICC in general as well as about their own possible role as participants." See Fiona McKay, Victim Participation in Proceedings before the International Criminal Court, HuM. RTS. BRIEF, Spring/Summer 2008, at 2, 4 .

43. For the English version, see INT'L CRIMINAL COURT, APPLICATION FORM FOR INDIVIDUALS: REQUEST FOR PARTICIPATION IN PROCEEDINGS AND REPARATIONS AT THE ICC FOR INDIVIDUAL VICTIMS, available at http:/www.icc-cpi.int/NR/rdonlyres/48A75CF0-E38E-48A7-A9E0026ADD32553D/0/SAFIndividualEng.pdf. 
requires energy and time, resources that those victims who struggle for survival on a day-to-day basis often cannot spare. As one report on obstacles to participation asks rhetorically,

The question is: how will victims be able to participate in the proceedings before the ICC while their basic needs such as housing and medical assistance remain unmet? Is the participation of victims in the process meaningful if their dignity is not first restored and their social and economic rights upheld? Indeed, how will victims be able to participate in a meaningful manner if they continue to eke out a meagre existence almost five years after the violence ended?

Even those victims who do manage to fill out application forms and to provide identifying documents do not necessarily obtain recognition. In the confirmation-of-charges hearing for Callixte Mbarushimana, the judges ruled that the applications of 470 victims would be left out because the Registry did not have the resources to process them by the deadline. ${ }^{45}$ Furthermore, in some situations, the court requires individuals who have been granted victim status at one stage of the proceedings to apply again for victim status at later stages. In sum, from the perspective of conflict-affected individuals seeking recognition as juridical agents, obtaining victim status at the ICC can be complex, time consuming, and tenuous.

The narrowing of the victim pyramid is not only a vertical dynamic. Its width fluctuates with changing case law. The drafters of the Rome Statute left much of the legal framework governing victim participation to be determined by ICC judges. The key article of the Rome Statute, article 68(3), establishes that "[w]here the personal interests of the victims are affected, the Court shall permit their views and concerns to be presented and considered at stages of the proceedings determined to be appropriate by the Court," leaving individual chambers to decide when personal interests are affected, what constitutes views and concerns, and at what point victims may participate. The degree of permissiveness has varied over time and across chambers. In the early stages of the court's lifespan, a pre-trial chamber permitted general participation by victims at the investigation stage ${ }^{46}$ but this right was then restricted on appeal. ${ }^{47}$

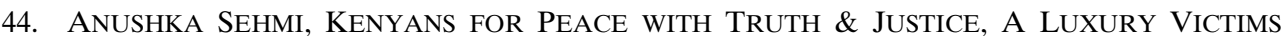
CANNOT AFFORD: MEANINGFUl PARTICIPATION AT THE INTERNATIONAL CRIMINAL COURT 5 (2013), available at http://www.africog.org/sites/default/files/A\%20Luxury\%20Victims\%20Cannot \% 20Afford\%20-\%20KPTJ\%20JULY\%202013.pdf.

45. Prosecutor v. Mbarushimana, Case No. ICC-01/04-01/10, Decision Requesting the Parties to Submit Observations on 124 Applications for Victims' Participation in the Proceedings, Pre-Trial Chamber I Doc. No. 265, 6 (July 4, 2011), http://www.icc-cpi.int/iccdocs/doc/doc1103372.pdf.

46. Situation in the Democratic Republic of the Congo, Case No. ICC-01/04, Decision on the Applications for Participation in the Proceedings of VPRS 1, VPRS 2, VPRS 3, VPRS 4, VPRS 5 and VPRS 6, Pre-Trial Chamber I Doc. No. 101-tEN-Corr, II 65 (Jan. 17, 2006), http://www.icc-cpi.int/ iccdocs/doc/doc183441.pdf.

47. Situation in the Democratic Republic of the Congo, Case No. ICC-01/04, Judgment on Victim Participation in the Investigation Stage of the Proceedings in the Appeal of the OPCD Against the Decision of Pre-Trial Chamber I of 7 December 2007 and in the Appeals of the OPCD and the Prosecutor Against the Decision of Pre-Trial Chamber I of 24 December 2007, Appeals Chamber Doc. No. 556 (Dec. 19, 2008), http://www.icc-cpi.int/iccdocs/doc/doc612293.pdf. 
Participatory rights at the trial stage have varied as well. One of the trial chambers granted victim status to "victim[s] of any crime falling under the jurisdiction of the Court." 48 This meant that in effect even victims of crimes not charged in the case under consideration could participate in the trial, thus broadening the pyramid. The court's appeals chamber overturned this broad grant of participatory rights, however, by claiming that the harm and the concept of personal interests under article 68(3) of the statute must be linked with the charges against the accused. ${ }^{49}$ This decision again narrowed the scope of possible victim participants at trial.

Finally, even recognized victims are sometimes unable to practice their participatory rights because the court is unable to obtain the relevant suspect. Victims in the Ugandan context have faced this circumstance. They enjoy formal status before the court, but because the defendant members of the Lord's Resistance Army have not been arrested, the victims' substantive participatory rights have been deferred. ${ }^{50}$

Even when recognized and able to exercise the right to participate, victims are still represented by counsel, references to victims as "participants" or even "actors" in the context of the ICC notwithstanding. ${ }^{51}$ As one trial chamber judge observed,

It needs to be remembered that this is a court of law and, in particular, this is the criminal trial of the accused, and the presumption is that those who participate in the proceedings will be lawyers, lawyers acting for individuals or for bodies, for entities.

While representational practices generally involve "making present in some sense of something which is nevertheless not present literally or in fact," particularly so with victims before the ICC. Although a given victim's relationship with counsel is sometimes described as an "attorney-client"

48. Prosecutor v. Lubanga, Case No. ICC-01/04-01/06, Decision on Victims' Participation, Trial Chamber I Doc. No. 1119, IIII 93, 95 (Jan. 18, 2008), http://www.icc-cpi.int/iccdocs/doc/doc409168.pdf (interpreting the scope of rule 85).

49. Lubanga, Case No. ICC-01/04-01/06, Judgment on the Appeals of the Prosecutor and the Defence against Trial Chamber I's Decision on Victims' Participation of 18 January 2008, Appeals Chamber Doc. No. 1432, II II 40-66 (July 11, 2008), http://www.icc-cpi.int/iccdocs/doc/doc529076.pdf.

50. See, e.g., Prosecutor v. Kony, Otti, Odhiambo \& Ongwen, Case No. ICC-02/04-01/05, Decision on Legal Representation of Victims a/0065/06, a/0066/06, a/0068/06, a/0088/06, a/0090/06 to a/0096/06, a/0098/06, a/0102/06, a/0103/06, a/0112/06, a/0115/06, a/0117/06, a/0118/06, a/0120/06 to a/0126/06, a/0076/07 to a/0078/07, a/0081/07, a/0082/07, a/0084/07, a/0085/07, a/0090/07 to a/0103/07, a/105/07 to a/0108/07, a/0112/07, a/0115/07, a/0117/07, a/0118/07 and a/0123/07, Pre-Trial Chamber II Doc. No. 336 (Feb. 9, 2009), http://www.icc-cpi.int/iccdocs/doc/doc629125.pdf.

51. See Int'l Criminal Court, Assembly of States Parties, 5th Sess., May 17-28, 2004, Regulations of the Court, ICC Doc. ICC-BD/01-01-04 (May 26, 2004), available at http://www.icc-cpi.int/NR/rdonlyres/ B920AD62-DF49-4010-8907-E0D8CC61EBA4/277527/Regulations_of_the_Court_170604EN.pdf; see also Luis Moreno-Ocampo, supra note 16.

52. Situation in the Democratic Republic of the Congo, Case No. ICC-01/04-01/06, Transcript of Status Conference, Doc. No. T-101-ENG, 43:11-14 (Jan. 12, 2009), http:/www.icc-cpi.int/iccdocs/doc/ doc617156.pdf (statement of Presiding Judge Adrian Fulford).

53. See PITKIN, supra note 5, at 8-9. 
relationship ${ }^{54}$ structural constraints often dilute this relationship. First, victims do not have an unqualified right to have their own individual attorney. ${ }^{55}$ The chamber can ask them to be represented by common legal representatives, ${ }^{56}$ who typically represent between hundreds and thousands of individuals. ${ }^{57}$ Second, geographical separation weakens the relationship between the victim and the counsel. Victims have few opportunities for direct contact with their representatives, who are often based in The Hague and rarely go on "missions" to "the field." S8 Some common legal representatives have their own "field assistants" who act as a channel of communication between them and the victims. While establishing a connection between the victim and the courtroom, the field assistant acts as another link in the chain of representation. In this sense, the victim is thus not represented but re-represented.

The relationship between victims and counsel also changes as a result of evolving case law. For instance, the trial chamber in the Kenyan cases presumed that victims' interests would be better represented if the common legal representative was based in Kenya as opposed to in The Hague, arguing that "greater geographic proximity between victims and the Common Legal Representative is important to ensure that victims can communicate easily and personally with their representative and thus ensure meaningful

54. Interview by Sara Kendall \& Chris Tenove with field assistants of the common legal representative in Prosecutor v. Ruto \& Sang (Kenya I) and Kenya II, Int'l Criminal Court (July 25, 2012).

55. Prosecutor v. Bemba, Case No. ICC-01/05-01/08, Decision on Common Legal Representation for the Purpose of Trial, Trial Chamber III Doc. No. 1005, II 16 (Nov. 10, 2010), http://www.icc-cpi.int/ iccdocs/doc/doc965368.pdf ("[C]ommon legal representatives are chosen by the Court, as opposed to by the victims themselves.").

56. See Int'l Criminal Court, RPE, supra note 10, at r. 90(2)-(3); see also, e.g., Prosecutor v. Gbagbo, Case No. ICC-02/11-01/11, Decision on Victims' Participation and Victims' Common Legal Representation at the Confirmation of Charges Hearing and in the Related Proceedings, Trial Chamber V Doc. No. 498 (June 4, 2012), http://www.icc-cpi.int/iccdocs/doc/doc1423293.pdf; Kenya II, Case No. ICC-01/09-02/11, Decision on Victims' Representation and Participation, Pre-Trial Chamber I Doc. No. 138, II 20 (Oct. 3, 2012), http://www.icc-cpi.int/iccdocs/doc/doc1479387.PDF.

57. According to a 2012 report on the court's activities, there were twenty-four external common legal representatives in eleven teams working on behalf of victims. The report claims that the court's own internal Office of Public Counsel for Victims represented approximately 4000 victims in 2012, with the number of victims represented by that office increasing by nearly seventy percent that year. Int'l Criminal Court, Assembly of States Parties, 11th Sess., Nov. 14-22, 2012, Report on the Activities of the Court, ICC Doc. ICC-ASP/11/21 (Oct. 9, 2012) [hereinafter Int'l Criminal Court, Report on the Activities of the Court], available at http://www.icc-cpi.int/iccdocs/asp_docs/ASP11/ICC-ASP-11-21ENG.pdf. At the time of writing, the number of recognized victim participants in the Bemba case in the situation of the Central African Republic exceeded 5000; meanwhile the Registry has been instructed by the trial chamber to appoint $t w o$ common legal representatives to "represent the totality of victims to be allowed to participate in the trial." Bemba, Case No. ICC-01/05-01/08, Decision on Common Legal Representation for the Purpose of Trial, Trial Chamber III Doc. No. 1005, II 7 (Nov. 10, 2010), http://www.icc-cpi.int/iccdocs/doc/doc965368. At present, recognized victims in other cases number in the hundreds.

58. Even when representatives travel to "the field," victims may not be able to meet with them on account of lacking the means to cover the costs of transport to the meeting or the time off work. See SEHMI, supra note 44. 
representation." ${ }^{59}$ Although the decision narrows the geographical distance between the representative and the victims, it also increases the distance between the representative and the court: When the common legal representative is based on site, he or she in turn is generally represented in the courtroom by the ICC's Office of Public Counsel for Victims (OPCV). In this scenario, the OPCV is not directly representing victims, but is "acting on the Common Legal Representative's behalf." ${ }^{60}$ The links in the chain have been reshuffled, but the re-representation continues.

At the same time, the trial chamber's decision enhanced access for victims (and reduced the workload for judges) by dropping the requirement that victims apply to the court for victim status and then be vetted judicially. Only victims who wish to appear directly before the chamber still need to fill out participation forms. Others may be "registered" as victim participants with the ICC Registry, which will enter their details into a database.${ }^{61}$ However, what is gained in access may be lost in meaning. Registration is easier than applying for status as a victim participant, but registration itself appears to be more a gesture of identification than an act leading to tangible outcomes. These "registered" victims are not officially granted victim status by the court. Instead, they become part of an amorphous category of victims whose views can be presented

59. Kenya II, Case No. ICC-01/09-02/11, Decision on Victims' Representation and Participation, II 59, Trial Chamber V Doc. No. 498 (Oct. 3, 2012), http://www.icc-cpi.int/iccdocs/doc/doc1479387.PDF; see also Kenya I, Case No. ICC-01/09-01/11, Decision on Victims' Representation and Participation, Trial Chamber V Doc. No. 460, II II 29, 60 (Oct. 3, 2012), http://www.icc-cpi.int/iccdocs/doc/ doc1479374.pdf. Changes in the victim-representation regime were largely inspired by practical reasons. The Kenya I decision notes that

[i]n the present case, due to the number of charges and the widespread nature of the alleged crimes, the number of eligible victims is estimated to be in the thousands. If all victims were required to comply with the procedure set out in Rule 89 of the Rules, for practical reasons it would not be possible to process all of the applications before the start of the trial, scheduled for April 2013.

Kenya I, Case No. ICC-01/09-01/11, Decision on Victims' Representation and Participation, Trial Chamber V Doc. No. 460, Trial Chamber V Doc. No. 460, If 30 (Oct. 3, 2012), http://www.icc-cpi.int/ iccdocs/doc/doc1479374.pdf.

60. Kenya I, Case No. ICC-01/09-01/11, Decision on Victims' Representation and Participation, Trial Chamber V Doc. No. 460, II 41 (Oct. 3, 2012), http://www.icc-cpi.int/iccdocs/doc/doc1479374.pdf. The decision continues, "The OPCV's primary responsibility will be to act as the interface between the Common Legal Representative and the Chamber in day-to-day proceedings. To that end, the OPCV will be allowed to attend hearings on behalf of the Common Legal Representative." Id. II 43. The common legal representative may appear for opening and closing statements and may request appearances at other points during the trial proceedings. Id. II 71.

61. Kenya II, Case No. ICC-01/09-02/11, Decision on Victims' Representation and Participation, Trial Chamber V Doc. No. 498, III 24, 48 (Oct. 3, 2012), http://www.icc-cpi.int/iccdocs/doc/doc1479387; see also Kenya I, Case No. ICC-01/09-01/11, Decision on Victims' Representation and Participation, Trial Chamber V Doc. No. 460, IIT 25, 49 (Oct. 3, 2012), http://www.icc-cpi.int/iccdocs/doc/ doc1479374.pdf. According to one staff member of the VPRS, however, the term "register" is problematic given the broader context of "registrations" that victims of the 2007 and 2008 postelection violence had been asked to participate in, including for the Truth, Justice and Reconciliation Commission of Kenya. The staff member was also concerned that the term implied reparations and compensation, and elected to use the term "verification" instead. Interview by Sara Kendall with staff member, Victims Participation \& Reparations Section, Int'l Criminal Court (Mar. 4, 2013). 
according to the discretion of their common legal representative. ${ }^{62}$ As the trial chamber noted, "while it is practically impossible to represent the individual views and concerns of thousands of victims, it is possible to represent their interests by voicing their shared legal and factual concerns in the present proceedings." ${ }^{63}$ The chamber thus tasks the common legal representative with distilling generalizable "interests" from the more unwieldy and personal "views and concerns" to which article 68(3) of the Rome Statute refers. ${ }^{64}$ Streamlining the practice of victim representation thus also produces the "oracle effect" of representation identified by Bourdieu: When appearing on behalf of absent constituents-the victims of a particular case-the representative "gives voice" to an abstract collectivity. ${ }^{65}$

Under this modified set of representational practices, the legal representative in fact has considerable discretion. When distilling generalizable "interests," the legal representative filters, weighs, and selects possibly diverging views. The legal representative could decide to reveal differences of opinion among victims, but in doing so, he or she risks working against some of the interests of individual victims. ${ }^{66}$ In Bruno Latour's terminology, legal representatives thus act as "mediators" and not as "intermediaries": Rather than merely channelling views, the legal representatives "transform, translate, distort, and modify that meaning of the elements they are supposed to carry." ${ }^{67}$

The legal representative's discretion is enhanced by the trial chamber's decision that the abstract collectivity of victims that the representative represents extends beyond the registered victims. In the chamber's words,

$[\mathrm{T}]$ he Chamber decides that the views and concerns of victims who choose not to register or who are, for practical or security reasons barred from doing so, shall nevertheless be voiced, in a general way, through common legal representation.... During the trial phase all victims, regardless of whether they have registered or not, will be represented through common legal representation.

62. For example, a submission from a common legal representative on where the trials should take place-in either The Hague, Arusha, or in Kenya-presented the different views of part of his pool of represented victims, but he advocated for a different location than the majority of those surveyed. Kenya I, Case No. ICC-01/09-01/11, Common Legal Representative for Victims' Observations in Relation to the "Joint Defence Application for Change of Place Where the Court Shall Sit for Trial," Trial Chamber V Doc. No. 620 (Feb. 22, 2013), http://www.icc-cpi.int/iccdocs/doc/doc1556944.pdf.

63. Kenya II, Case No. ICC-01/09-02/11, Decision on Victims' Representation and Participation, Trial Chamber V Doc. No. 498, II 59 (Oct. 3, 2012), http://www.icc-cpi.int/iccdocs/doc/doc1479387.PDF.

64. See Rome Statute, supra note 3, at art. 68(3).

65. See BOURDIEU, supra note 7.

66. One common legal representative recounted that the common legal representatives needed clarification regarding the extent of their mandate due to the diversity of interests among the populations they represent, where sometimes their interests may be conflicting. Interview by Sara Kendall with common legal representative, Int'l Criminal Court (Mar. 1, 2013).

67. BRUNO LATOUR, REASSEMBLING THE SOCIAL: AN INTRODUCTION TO ACTOR-NETWORKTHEORY 39 (2005).

68. Kenya II, Case No. ICC-01/09-02/11, Decision on Victims' Representation and Participation, Trial Chamber V Doc. No. 498, II 52 (Oct. 3, 2012), http://www.icc-cpi.int/iccdocs/doc/doc1479387.PDF. 
This decision appears to leave no opt-out procedure for victims who choose not to be represented, or indeed, for victims who explicitly state a desire to withdraw from ICC proceedings because they have no "confidence that the process would be beneficial to them," as did a large number of court-recognized victim participants in one of the Kenyan cases. ${ }^{69}$ Without a legal avenue for resisting representation as part of an abstract collectivity, even victims who do not want to have anything to do with the ICC can thus be "symbolically" "made present" in a case before the court. ${ }^{70}$ In the words of the chamber, "[A]11 victims ... will be represented."

At the apex of the pyramid of juridified victimhood are the victims who wish to present their views and concerns individually by appearing directly before the chamber and have passed through the vetting process of the court with its attendant participation forms and application deadlines, submissions by the parties and rulings by the judges, and who have an accused in the dock. Having reached the summit, however, the "participating" victim in fact often has quite an inactive role. ${ }^{72}$ Direct participation is exceptionally rare. As one trial chamber judge explains,

If individuals are allowed to participate in person, there would have to be cogent, indeed powerful, reasons for that exceptional course ... because . . people without legal training coming to talk about very difficult things that have happened to them could have a real capacity for destabilising these court proceedings .... So we're not saying no, but we're saying exceptional and for good reason.

Indeed, the number of victim participants who, once channeled through the institutional machinery of the court, directly address a chamber of the ICC is remarkably low. One victim was permitted to present views before the appeals chamber in an appeal in the Uganda situation. ${ }^{74}$ Three individual victims were permitted to testify in Prosecutor v. Lubanga; their testimony was subsequently dismissed as unreliable. ${ }^{75}$ In the Katanga trial, the chamber authorized four individuals out of a group of over 300 recognized victims to appear before the

69. Isaiah Lucheli, Ninety Three Post Election Violence Victims Withdraw From International Criminal Court Proceedings, STANDARD DigiTAL (June 7, 2013), https://www.standardmedia.co.ke/ ?articleID=2000085360\&story_title=93-pev-victims-withdraw-from-icc-proceedings (Kenya).

70. See BOURDIEU, supra note 7; PITKIN, supra note 5.

71. See supra text accompanying note 68 .

72. An independent report on victim participation at the ICC noted that "[g]enuine concerns ... exist that participation is currently not meaningful for victims who are accepted to participate," and elaborated that victim participants were unable "to present their views at appropriate stages." INDEPENDENT PANEL OF EXPERTS REPORT ON VICTIM PARTICIPATION AT THE INTERNATIONAL CRIMINAL COURT II 39 (2013), available at http://www.redress.org/downloads/publications/ 130711\%20panel\%20report\%20FINALfor\%20dissemination.pdf.

73. Situation in the Democratic Republic of the Congo, Case No. ICC-01/04-01/06, Transcript of Status Conference, 43:15-44:3 (Jan. 12, 2009), http://www.icc-cpi.int/iccdocs/doc/doc617156.pdf (statement of Presiding Judge Adrian Fulford).

74. Prosecutor v. Kony, Otti, Odhiambo \& Ongwen, Case No. ICC-02/04-01/05, Decision on the Participation of Victims in the Appeal (Oct. 27, 2008), http://www.icc-cpi.int/iccdocs/doc/doc580160.pdf.

75. Prosecutor v. Lubanga, Case No. ICC-01/04-01/06, Judgment Pursuant to Article 74 of the Statute, II 499 (Mar. 14, 2012), http://www.icc-cpi.int/iccdocs/doc/doc1379838.pdf. 
court $;^{76}$ however, two of them were considered unreliable before they even came to The Hague. ${ }^{77}$ In the Bemba trial, a total of five individuals out of over 5000 recognized victims have appeared to date. ${ }^{78}$

Ultimately, even for those victims who participate, their status always remains merely provisional. This is because judges recognize victims before any alleged facts have been proven. There cannot be definite victims of unproven acts; therefore, victim recognition is necessarily provisional. In the case of an acquittal, victims will lose their victim status (unless there are coaccused, charged with the same crimes and incidents). But even in the case of a conviction, victims' position as victims will seldom be confirmed in the judgment: The judgment focuses on the guilt of the accused and need not determine the relationship between the accused and the participating victims.

Perhaps it is only in the subsequent reparations proceedings that victims can be considered to obtain final recognition. However, this decision is not dependent on the victims' participation in the trial: Victims can also apply for reparations without participating. Contrary to the widespread rhetoric of victims gaining "recognition" through the ICC, victims thus never receive recognition as participants in the proceedings in a strict judicial sense. Moreover, even in the reparation procedures, victims may not obtain final judicial recognition of individual victimhood. In the court's first decision on victims' reparations, the judges established only the principles; they left it up to the Trust Fund for Victims, a nonjudicial body, to grant reparations accordingly. ${ }^{79}$

Of the millions of victims in the world, then, only thousands have managed to reach the top of the pyramid of juridified victimhood and have been granted provisional recognition as victims before the ICC. To date only a handful of these have been permitted to speak directly in ICC proceedings. The remainder are "made present" through the work of their legal representatives. Through the "oracle effect" of representational practice, these individuals are constituted as a group to be spoken for, and in turn their spokesperson (and indeed the court itself) appropriates the "authority of that elusive, absent phenomenon."

76. As of October 2012, the Katanga case had 366 recognized victims. Int'l Criminal Court, Report on the Activities of the Court, supra note 57, at pt. IV.

77. Prosecutor v. Ngudjolo, Case No. ICC-01/04-02/12, Judgment Pursuant to Article 74 of the Statute, II 32 (Dec. 18, 2012), http://www.icc-cpi.int/iccdocs/doc/doc1579080.pdf. On February 21, 2011, the chamber heard testimony of the remaining two victim participants. Ngudjolo, Case No. ICC-01/0402/12, Transcript of Trial Hearing (Feb. 21, 2011), http://www.icc-cpi.int/iccdocs/doc/doc1245216.pdf.

78. Two individuals appeared in person in May 2012; three more testified in June 2012 via videolink.

79. Lubanga, Case No. ICC-01/04-01/06, Decision Establishing the Principles and Procedures to be Applied to Reparations, Trial Chamber I Doc. No. 2904 (Aug. 7, 2012), http://www.icc-cpi.int/ iccdocs/doc/doc1447971.pdf.

80. BOURDIEU, supra note 7, at 211. 
III

\section{TRANSCENDING THE PYRAMID-"ThE Victims" AS ABSTRACTION}

Practices of victim representation are not confined to the courtroom. Outside the courtroom, victims are also represented-and at an even greater degree of abstraction-by diplomats, politicians, ICC officials, NGOs, journalists, and scholars. Discursively, victims are presented as the raison d'être of the ICC. ${ }^{81}$ Indeed, victims are figured as animating and giving purpose to the entire machinery of international criminal accountability: Even international criminal tribunals that do not have a practice of victim participation have invoked victims as one of the justifications for their work. ${ }^{82}$ References to victims serve as reminders of this group's seemingly fundamental position in international criminal law regardless of whether they hold a position as participant.

However, the fact that victims have also been invoked by tribunals that do not have a practice of victim participation shows that the invocation of victims as the justification of the international-criminal law project is not necessarily a reference to the victims that participate in courtroom proceedings. The rhetoric of the role of the victim in the ICC transcends legally recognized victims. Indeed it transcends actual victims with their individuated harms and suffering. The "victims"-whom the court's first prosecutor referred to when he said that his mandate was "justice for the victims," mind when she pronounced that the "sole raison d'etre of the ICC's activities in Côte d'Ivoire is the victims," ${ }^{, 4}$ whom the court's president brought up when he made an appeal not to "let down the countless victims around the world that place their hope in this institution," ${ }^{85}$ whom the appeals chamber invoked when referring to "thousands of victims," speaking of the "overriding interest ... of the victims," ${ }^{, 7}$ whom NGOs rely on when stating that "victims want justice" and when evoking an image of

81. See, e.g., Press Release, Office of the Prosecutor, ICC Prosecutor Visits Egypt and Saudi Arabia, supra note 18; Silvana Arbia, Registrar, Int'l Criminal Court, Remarks to the 11th Session of the Assembly of States Parties (Nov. 4, 2012) (transcript available at http://www.icc-cpi.int/NR/ rdonlyres/F1E2BCA9-4F55-4C1C-938B-2107233D0A98/0/ASP11OpeningREGSA1ENG.pdf).

82. Victims' interests were not, however, the rationale for international criminal law in its early stages of development. See Conor McCarthy, Victim Redress and International Criminal Justice: Competing Paradigms, or Compatible Forms of Justice?, 10 J. INT'L CRIM. JUST. 351, 352 (2012).

83. Press Release, Office of the Prosecutor, ICC Prosecutor Visits Egypt and Saudi Arabia, supra note 18.

84. $I d$.

85. Press Release, Office of the Prosecutor, Prosecutor's Statement to the Press from Abidjan, supra note 19.

86. Press Release, Office of the Prosecutor, ICC Launches Commemorations for International Criminal Justice Day, supra note 20.

87. Prosecutor v. Katanga, Case No. ICC-01/04-01/07, Judgment on the Appeal of Mr. Germain Katanga against the Oral Decision of Trial Chamber II of 12 June 2009 on the Admissibility of the Case, Appeals Chamber Doc. No. 1497, II 79 (Sept. 25, 2009), http://www.icc-cpi.int/iccdocs/doc/ doc746819.pdf. 
"thousands of children, women and men who are victims of crimes within the Court's jurisdiction," court will act ${ }^{89}$-are not specific individuals. Instead, in these contexts, "the victims" is a reference to an abstraction-"The Victims"-which is based on the idea of victims. Grammatically plural but treated as singular, this abstraction in fact effaces individuality and transforms victims into a homogenous unity, like "the masses," "the general will," or "the people." In the words of Bourdieu, this constitution of a unified figure is "an act of magic which enables what was merely a collection of several persons, a series of juxtaposed individuals, to exist in the form of a fictitious person, a corporatio, a body, a mystical body incarnated in a social body, which itself transcends the biological bodies which compose it." ${ }^{90}$

As abstraction, "The Victims" acts in some ways as the absent "sovereign" of international criminal law. In the field of public international law, which lacks its own sovereign, "The Victims" appears rhetorically as the one in whose name criminal justice is exercised. Like national prosecutions carried out on behalf of the crown or the state, the ICC is said to speak on behalf of the victims of "the most serious crimes of concern to the international community." "The Victims" thus seems to serve as the highest symbolic entity within this juridical domain, in whose name justice is done. Yet as with nationalist symbols such as tombs of the Unknown Soldier-which, as Benedict Anderson observes, are revered "precisely because they are either deliberately empty or no one knows who lies inside them" — "The Victims" does not correspond to a concrete, material referent. It stands for collective suffering produced through international crimes without containing the particular suffering of wronged individuals.

Like a sovereign, "The Victims" as an abstraction hovers over and above, but is not part of, the pyramid of victimhood. "The Victims," as opposed to individual victims, also enjoys immunity from challenge. Challenging the suffering of any individual is difficult since suffering is inherently personal. ${ }^{93} \mathrm{But}$ it is even more difficult to challenge the suffering of an abstract entity such as "The Victims" because that suffering is an amalgamation of individual pain that cannot be traced to a single individual. This collective suffering has been experienced by all victims together, while no single individual has experienced

88. Press Release, Secretary-General, UN Secretary-General Declares Overriding Interest of International Criminal Court Conference Must Be That of Victims and World Community as a Whole, supra note 22.

89. Niccolò Figà-Talamanca, supra note 23.

90. BOURDIEU, supra note 7, at 208.

91. Rome Statute, supra note 3, at pmbl.

92. BENEDICT ANDERSON, IMAGINED COMMUNITIES: REFLECTIONS ON THE ORIGIN AND SPREAD OF NATIONALISM 9 (1991).

93. See Ian Buruma, The Joys and Perils of Victimhood, N.Y. REv. BooKs, Apr. 8, 1999, available at http://www.nybooks.com/articles/archives/1999/apr/08/the-joys-and-perils-of-victimhood/; Martha Minow, Surviving Victim Talk, 40 UCLA L. REV. 1411, 1436-38 (1993). 
it all. Consequently, the suffering of "The Victims" cannot be questioned, nor can claims made on its behalf be contested by the concrete particularity of individual experience: "The Victims" is untouchable.

The untouchable authority of "The Victims" is sometimes invoked to shield the court from criticism. For example, in response to the growing claim that the ICC has been selectively targeting the African continent in prosecuting individuals for international crimes, the current prosecutor has stated,

[i]f we are thinking about the victims of these crimes, the victims of these atrocities who are also vulnerable African victims, then we would not think about targeting Africans. We will be thinking about, working for and supporting the victims of these crimes.

The moral currency of victimhood is thus appropriated to shore up the legitimacy of the ICC's actions. ${ }^{95}$ In line with Bourdieu's analysis of representative practice, although "The Victims" does not exist without being discursively represented as such, "The Victims" does confer authority on those who claim to represent it.

"The Victims" is a convenient telos for the ICC not only because third parties cannot impeach an organization that represents the interests of "The Victims," but also because "The Victims" themselves cannot impeach the representative: An abstraction cannot speak back. In the event that specific victims disagree with the justice conducted in their name-for instance, as with the Kenyan victims mentioned above-the abstraction of "The Victims" serves as a reservoir of other victims who could be said to wait for the court's intervention. Victims silenced by death provide an inexhaustible justification of the ICC as a retributive mechanism. Potential future victims, in turn, will continue to justify the ICC as a means for deterring harm yet to come. In their absence, dead or future victims are paradoxically made present: they have been there and they will be there to be spoken for. As such, they are always available for invocation as the underlying purpose of the project, without threatening resistance or articulating other desires. ${ }^{96}$

Although "The Victims" is seemingly sovereign in a symbolic register, as when crimes are prosecuted on behalf of the crown, the abstraction does not actually exercise power itself. Instead it works as a placeholder for the agency of others: The rhetoric of "The Victims" presents victims not only as the underlying justification of the international criminal legal order, but also, as Kamari Clarke has argued, as a helpless and potential beneficiary of

94. Peter Clottey, ICC Prosecutor Hails US International Justice Role, VOICE OF AM. (Apr. 4, 2013), http://www.voanews.com/content/icc-prosecutor-hails-us-international-justice-role/1635160.html; see also Victims Must Not Be Forgotten on International Justice Day: Civil Society Underlines Hope for Victims of Grave Crimes That Rome Statute System Represents, COALITION FOR INT'L CRIM. CT., $\mathrm{http} / /$ us2.campaign-archive2.com/?u=8758bcde31bc78a5c32ceee50\&id=0233ef45b6\&e=24df3e19c0.

95. See Ann Sagan, African Criminals/African Victims: The Institutionalised Production of Cultural Narratives in International Criminal Law, 39 MiLlenNIUM: J. INT’L STUD. 3 , 12 (2010).

96. S.M.H. Nouwen, Justifying Justice, in THE CAMBRIDGE COMPANION TO INTERNATIONAL LAW 327, 340 (James Crawford \& Martti Koskenniemi eds., 2012). 
international criminal law that requires a subject—-the agents of this field-to act for it and in its name. ${ }^{97}$ Presumptively new agents in international criminal law, victims are thus in fact dependent on the agency of a representative, both inside and outside the courtroom.

Those who work in and around the court are presented by the field of international criminal law as the field's actual agents. They consider themselves part of another abstraction: the "international community." The very grammar of common descriptions of the ICC's work suggests that justice is carried out in the name of "The Victims" by the "international community." "The Victims" thus appears as the passive object of an active subject. That subject is as abstract as its object: The boundaries of the "international community" are indeterminate, but whatever is within is presented as homogeneous, creating an impression of consensus among members of this discursively constituted "community." The OTP invokes and claims to represent the interests of both abstractions-"The Victims" and the "international community"-yet it belongs only to the latter. Speaking in the name of "The Victims" on behalf of the "international community," the OTP thus enjoys the rhetorical force of a double abstraction, wielding the power of both pathos and universal consensus.

This practice of representing abstractions is not so much a reflection of realities as it is constitutive of them. The "making present" of an acting "international community" helps to shape and construct an "international community" with an ability to act. The "making present" of victims as helpless, by contrast, reinforces passivity and dependence. ${ }^{98}$ The agency of "the international community" is constructed in response to and as the mirror image of the helplessness of "The Victims." For instance, when the ICC prosecutor announced the opening of an investigation into Mali, she stated:

My Office... will bring justice to Malian victims by investigating who are the most responsible for these alleged crimes.... There is still turmoil in North Mali and populations there continue to be at risk of yet more violence and suffering .... Justice can play its part in supporting the joint efforts of the ECOWAS, the AU and the entire international community to stop the violence and restore peace to the region."

Even when deciding to drop charges against an accused, ${ }^{100}$ as a result of which specific victims would lose their status as participants in a case before the ICC,

97. Kamari M. Clarke, Global Justice, Local Controversies: The International Criminal Court and the Sovereignty of Victims, in PATHS TO INTERNATIONAL JUSTICE: SOCIAL AND LEGAL PERSPECTIVES 134 (Tobias Keller \& Marie-Bénédicte Dembour eds., 2007) [hereinafter Clarke, Global Justice]; see also KAMARI M. Clarke, Fictions of Justice: The ICC AND THE Challenge OF LEgAl PluRALISM IN SUB-SAHARAN AFRICA (2009) [hereinafter ClARKE, Fictions OF JUSTICE].

98. MUTUA, supra note 10, at 27-38; see also Clarke, Global Justice, supra note 97.

99. Press Release, Office of Prosecutor, ICC Prosecutor Opens Investigation into War Crimes in Mali: "The Legal Requirements Have Been Met. We Will Investigate," ICC Press Release ICC-OTP20130116-PR869 (Jan. 16, 2013), available at http://www.icc-cpi.int/en_menus/icc/ press \%20and\%20media/press \%20releases/news\%20and\%20highlights/Pages/pr869.aspx.

100. Kenya II, Case No. ICC-01/09-02/11, Prosecution Notification of Withdrawal of the Charges against Francis Kirimi Muthaura, Office of the Prosecutor Doc. No. 687 (Mar. 11, 2013), http://www.icccpi.int/iccdocs/doc/doc1565549.pdf. 
the ICC prosecutor emphatically reiterated her commitment to the victims and stressed her own memory of them as a form of agency:

[L]et me remind you all of my unwavering commitment to justice for the victims of the 2007-2008 post-election violence. The real victims of the terrible violence in Kenya five years ago are the men, the women, and the children, who were killed, injured, raped, or forcibly displaced from their homes - and whose voices must not be forgotten. I will not forget them.

As this quote reveals, the practice of representing victims as objects of the agency of heroic interveners occurs in a discourse that is not purely legal or technical: As Susan Marks and Andrew Clapham have argued, it involves a degree of pathos and melodrama. ${ }^{102}$ The melodramatic representation of victims replaces their actual experience with "a cheap and ghastly imitation," exaggerating the relevant "plot" and "characters" in order to appeal to the observer's emotions. ${ }^{103}$ At the same time, those acting in the name of victims "represent" themselves as a heroic and powerful substitute, as "the holder of those values which the victim lacks." 104 "I am doing justice for you," the court's first prosecutor said to the people of northern Uganda. ${ }^{105}$ Rather than a position of empathy, the actor occupies a pleasurable position of compassion or even heroism, reimagining the world and the actor's own agency within it. ${ }^{106}$ As the first prosecutor recounts,

One of my investigators from Portugal interviewed a girl who was abducted when she was 11-years-old but later escaped. After 3 days, when the investigator had finished asking the questions the girls started to cry. My investigator felt bad. But the girl said: "Don't worry, I am not sad. I am crying because this is the happiest moment of my life. I have never had anyone pay such attention to what happened to me." What we are doing is helping the victims to be less of victims and more of citizens. It is my legal duty to grant such people justice.

Melodramatic in that it exaggerates the characters of the hero and the victim, this quote also reveals the circular relationship of representation that Bourdieu pointed to: The representative, the one who speaks on behalf of, is also dependent upon the authority conferred by the represented to speak in their

101. Press Release, Office of the Prosecutor, Statement by ICC Prosecutor on the Notice to Withdraw Charges against Mr Muthaura, ICC Press Release (Mar. 11, 2013), available at http://www.icc-cpi.int/en_menus/icc/press \%20and\%20media/press \%20releases/Pages/OTP-statement-

11-03-2013.aspx.

102. SUSAN MARKS \& ANDREW ClAPHAM, INTERNATIONAL HUMAN RIGHTS LEXICON 405 (2005); see also RoBERT MEISTER, AFTER EVIL: A POLITICS OF HuMAN RigHTS 72 (2011).

103. MARKS \& CLAPHAM, supra note 102.

104. Anne Orford, Muscular Humanitarianism: Reading the Narratives of the New Interventionism, 10 EUR. J. INT’L L. 679, 699 (1999); see also Clarke, Global Justice, supra note 97.

105. Felix Osike, Uganda: Kony Must Face Trial [at] ICC, NEW VISION (July 13, 2007), http://www.newvision.co.ug/D/8/13/575670 (Uganda).

106. See Robert Meister's critique of what he terms "humanitarian compassion": "[I]t makes us feel good about feeling bad, creating the delusion that compassion is its own reward." MEISTER, supra note 102, at 73. On heroism, see MARKS \& CLAPHAM, supra note 102, at 404. See also Clarke, Global Justice, supra note 97.

107. Felix Osike, Uganda: ICC Prosecutor L[]uis Ocampo in His Office at the Hague, NEW VISION (July 13, 2007), http://allafrica.com/stories/200707160105.html (Uganda). 
name. The heroic actor on behalf of the international community needs victims - or indeed "The Victims"- to exist and to continue to exist in order to justify the work of international criminal law.

The mutual dependence inherent in this circular relationship of representation in some instances creates a system of checks. This could be the case, as Bourdieu explains, when power is conferred from one person to another. ${ }^{108}$ Or, to put it in terms of legal representation, the more direct the mandate of representation, the stronger the check on the power of the representative. When the representative speaks on behalf of a collectivity, however, "that person can be invested with a power which transcends each of the individuals who delegate him," ${ }^{109}$ introducing a transcendent power into representational practice that is greater than the sum of the represented individuals. The check that the represented could theoretically exercise on the power of the representative is then operable only if the represented "can stand up and say "you are not the group." "110 In the context of ICC proceedings, exercising a check on the powers of those who discursively represent the victims is virtually impossible when represented individuals are increasingly displaced by the collective fiction of "The Victims," a fiction that cannot respond to claims made in its name.

The convenience of "The Victims," this figure that cannot contest its own representation, reveals what Bourdieu terms "the oracle effect," when a representative "gives voice to the group in whose name he speaks, thereby speaking with all the authority of that elusive, absent phenomenon."111 "The Victims" is not sufficiently tangible to contest the representative practices that are undertaken on its behalf. And yet as a rhetorical construct, this entity continues to provide a ready justification for the work of the ICC.

\section{IV \\ CONCLUSION}

Despite the frequent invocation of victims as actors, it has proven difficult to grant individual victims a place in the process of international criminal law. First, as the chambers have realized ${ }^{112}$ there are many victims of international

108. BOURDIEU, supra note 7, at 204.

109. Id. at 203.

110. Id. at 212 .

111. Id. at 211.

112. See, e.g., Kenya II, Case No. ICC-01/09-02/11, Decision on Victims' Representation and Participation, Trial Chamber V Doc. No. 498, II 20 (Oct. 3, 2012), http://www.icc-cpi.int/iccdocs/doc/ doc1479387.PDF. See also, in the context of reparations, the ICC Trial Chamber's decision on victims' reparations in Prosecutor v. Lubanga, Case No. ICC-01/04-01/06, Decision Establishing the Principles and Procedures to be Applied to Reparations (Aug. 7, 2012), http://www.icc-cpi.int/iccdocs/doc/ doc1447971.pdf (deciding to approach victims collectively). The Assembly of States Parties, too, is considering options for a more collective approach to victims' participation. See Int'l Criminal Court, Assembly of States Parties, Victims and Reparations, Res. 7, If 5, ICC Doc. ICC-ASP/11/Res.7 (Nov. 21, 2012), available at http://www.icc-cpi.int/iccdocs/asp_docs/Resolutions/ASP11/ICC-ASP-11-Res7- 
crimes. This has raised numerous managerial and financial problems in the current procedural setup. ${ }^{113}$ More fundamentally, as Martti Koskenniemi has observed concerning the role of the victim in the doctrine of humanitarian intervention, the victim is considered "worthy of humanitarian support as long as he remains a helpless victim - but turns into a danger the moment he seeks to liberate himself." ${ }^{114}$ As individual human beings, victims (in sharp contrast to "The Victims") are inherently political persons. As a political person-with interests and relationships and strategies - a victim carries a political narrative of the past and a vision for the future that may fit uneasily in the courtroom process, and indeed in the project of international criminal law more broadly. Victims as political persons may even oppose the use of international criminal law in response to the harms they have suffered, preferring other solutions to conflicts and alternate avenues of redress. ${ }^{115}$

One of the most common discursive practices for dealing with the complexities of the individual victim has been that of abstraction: to refer to "The Victims" collectively as opposed to specific victims. In this practice, the figure of "The Victims" has emerged as a seemingly sovereign placeholder of international criminal law. "The Victims" suggests a symbolic unity and authority, not unlike that other abstraction, "the international community," in whose name international criminal law is ostensibly carried out. It is also an authority that cannot be challenged because victims' experiences of suffering cannot be contested. As an abstraction, however, "The Victims" cannot call to account those who act in its name. International criminal law is thus carried out in the name of two abstractions, neither of which (unlike the state) has legal personality and neither of which can hold those who claim to represent it to account.

"The Victims" as an abstraction serves the project of international criminal law-itself a field that often disavows its own political origins and consequences $^{116}$ - more effectively than individual victims, with their particular circumstances, interests, and views of what justice ought to be. As an abstraction, "The Victims" can always be crafted as a mirror image: as the innocent mirror image of the criminal (for instance, the child soldiers vis-à-vis Lubanga),${ }^{117}$ as the helpless mirror image of international actors who must act in

ENG.pdf (requesting "the Bureau to prepare, in consultation with the Court, any amendments to the legal framework for the implementation of a predominantly collective approach in the system for victims to apply to participate in the proceedings").

113. For two accounts of these challenges from within the court, see McKay, supra note 42, and Van den Wyngaert, supra note 14.

114. Martti Koskenniemi, "The Lady Doth Protest Too Much": Kosovo, and the Turn to Ethics in International Law, 65 MOD. L. REV. 159, 173-74 (2002).

115. See supra note 28 and text accompanying note 69.

116. See, e.g., Sarah M.H. Nouwen \& Wouter G. Werner, Doing Justice to the Political: The International Criminal Court in Uganda and Sudan, 21 EUR. J.INT'L L. 941 (2010).

117. See Luis Moreno-Ocampo, Prosecutor, Int'l Criminal Court, Working with Africa: The View from the ICC Prosecutor's Office 9 (Nov. 9, 2009) (transcript available at http://www.icc-cpi.int/ NR/rdonlyres/1229900D-B581-42AE-A078- 
its name (for instance, the women, children, elderly, and men, victimized in the past or future, who presumably depend on NGOs and international courts to receive justice), and as the passive mirror image of an "international community" that is discursively constituted to act on its behalf. Commentators within and outside the legal community may have been inclined to disregard sweeping statements concerning "the victims" as the triumphalist language of diplomats and activists. However, dismissing this kind of representation because it is legally irrelevant fails to acknowledge that the invocation of "the victims" has become routinized in the discourse of the ICC. Indeed, it has become a regular practice. And, like other practices, practices of representing victims before the ICC are consequential. Both the representation of victim participants in courtroom proceedings and the discursive representation of "The Victims" are practices that generate conceptions, produce effects, and not only challenge but also sustain structures of power.

Insofar as practices amount to implementation of preconceived ideas-as is the case with laws - they are also "constitutive of social reality." 118 The practices of victim representation constitute social reality in at least three ways. First, these practices reinscribe the court's own authority through recourse to a presumptive set of constituents, namely the victims of crimes within its jurisdiction, who are to be represented through the ICC's work. The 2002 entry into force of the Rome Statute may serve as the ICC's original constitutive act, but its authority is continuously reconstituted through ritualized practices. As Davide Nicolini has observed, institutions are "kept in existence through the recurrent performance of material activities, and to a large extent they only exist as long as those activities are performed." ${ }^{119}$ Through its practices the ICC and its proponents continue to invoke the interests of victims as a basis of the court's activity and as a justification in the face of criticism.

Secondly, ICC representative practices generate and reinforce the idea of "The Victims," fostering particular conceptions of an individual's lived reality, forms of suffering, and desires for redress. ${ }^{120}$ This idea, in turn, has imperative

918550C372FB/281385/south_africa_nov_09_3finalfordistribution.pdf) ("The Africa bias is a baseless debate started and promoted by President Bashir... I will not apologize for protecting the rights of African victims. As Archbishop Tutu said, you have to choose your side, to protect the criminals or their victims.").

118. Adler \& Pouliot, supra note 2, at 12 (discussing the practice of bargaining); see also id. at 23.

119. DAVIDE NICOLINI, PRACTICE THEORY, WORK, AND ORGANIZATION: AN INTRODUCTION 3 (2013).

120. See more generally on the social construction of suffering, Arthur Kleinman, "Everything That Really Matters": Social Suffering, Subjectivity, and the Remaking of Human Experience in a Disordering World, 90 HARV. THEOLOGICAL REV. 315, 321 (1997) ("[S]uffering . . . is ... a professional discourse that organizes forms of suffering as bureaucratic categories and objects of technical intervention... suffering is social... because social institutions respond with assistance to certain categories of sufferers (categories that institutions have constructed as authorized objects for giving help), while denying others or treating them with bureaucratic indifference. Thereby social institutions, through their policies and programs, frequently deepen certain forms of social suffering and become obstacles to their alleviation." (citation omitted)). 
force: Implemented by the world's only permanent international criminal court and the influential epistemic community surrounding it, the idea of "The Victims" becomes a governing paradigm for how survivors of mass-atrocity crimes ought to articulate their suffering. Indeed, as the above statement from an international NGO asserts, recognition by the ICC is regarded as a means through which victims "can regain confidence in their ability to live." ${ }^{121}$ Put another way, in the words of the court's first prosecutor, "What we are doing is helping the victims to be less of victims and more of citizens." ${ }^{122}$ This idea of conflict survivors as passive figures requiring ICC intervention has become commonplace among those who advocate on behalf of victims:

For victims, a case before the ICC means that the international community hears their suffering, and cares enough to ensure that those responsible for their pain will not go unpunished .... Being an integral part of the process is also the first step towards giving victims back the dignity they had lost through these crimes. ${ }^{123}$

As it is presented in these statements, representation before the ICC enables individuals to regain their confidence, citizenship, and dignity-fundamental qualities that have presumably been lost, and that an entity such as the court can presumably recover. Presumptions aside, seeking redress through recognition by an entity such as the court is beset by the limitations and exclusions illustrated through the narrowing of the pyramid of juridified victimhood.

A third result of these practices is that actual victims are depoliticized. ${ }^{124}$ Disavowing the political aspects of victims' identities suppresses the extent to which survivors are actors with initiative and interests. ${ }^{125}$ Particularly, the practice of abstracting victimhood serves to suppress the victim's political interests. The more abstract the victim, the less political and thus the more suitable to international criminal law. Thus "The Victims"- as an abstraction that cannot speak back-is a safe and available substitute for actual victims in the discourse of international criminal law. Meanwhile, leaving agency to those who purport to represent victims enhances these agents' own resources, power, and status. The increasing gap between the discourse and reality of victim participation is thus also an increasing gap between those who represent and those who are represented.

In sum, in the practices of the ICC-which in this context involves not merely the court, but also the epistemic community surrounding it-victims are both overdetermined and less represented than the claims suggest. They are overdetermined in that all victims are amalgamated into an abstract entity, "The Victims," which serves as a rhetorical justification and rationalization of

121. Niccolò Figà-Talamanca, supra note 23.

122. Osike, supra note 107.

123. Victims' Rights Working Group, Statement at the 11th Session of the Assembly of States Parties (Nov. 15, 2012).

124. See Clarke, Global Justice, supra note 97.

125. See BRANCH, supra note 10; MARKS \& ClAPHAM, supra note 102, at 404. 
the project of international criminal law. Meanwhile, as a result of juridification, very few individuals are actually personally represented in legal proceedings. This gap between the discourse surrounding victim representation and what transpires in the court's work-namely between the presentation of "The Victims" as the raison d'être of international criminal law and the very limited role of victims in international criminal proceedings-coincides with a gap between the victim as an abstraction and as an actual victim of mass atrocity. Kamari Clarke explains this dynamic in recounting how victims are paradoxically central as well as marginal: "[I]nstitutions such as the International Criminal Court actually draw their power from the imaginary of the victim, whose liberation is possible only through suffering; the victim figure thus remains both central and marginal to the process." ${ }^{126}$ The overdetermined presence of the figure of "The Victims" as a rhetorical construct obscures the representative challenges faced by conflict-affected individuals in accessing the form of justice that is practiced in their (abstract) name. And yet, even though an ICC trial chamber seems to have adjusted the promise of participation to a more modest reality, ${ }^{127}$ the discourse produced through agents acting on victims' behalf continues to portray "The Victims" as the telos of international criminal law.

126. ClaRKE, FICTIONS OF JUSTICE, supra note 97, at 237.

127. Kenya II, Case No. ICC-01/09-02/11, Decision on Victims' Representation and Participation, Trial Chamber V Doc. No. 498, II 20 (Oct. 3, 2012), http://www.icc-cpi.int/iccdocs/doc/doc1479387.PDF. 